\title{
Practical Experience of the Art and Exhibition Activity at the Enterprises of Hotel Services in the Russian Federation
}

\author{
Liliya Leonidovna Dukhovnaya
}

Institute for tourism and hospitality affiliate of Russia State University of Tourism and Services Studies, 125438, Moscow, Kronshtadskiy avenue, 32-A

Irina Ivanovna Kholodtsova

Institute for tourism and hospitality affiliate of Russia State University of Tourism and Services Studies, 125438, Moscow, Kronshtadskiy avenue, 32-A

Vladimir Vladimirovich Polyakov

Institute for tourism and hospitality affiliate of Russia State University of Tourism and Services Studies, 125438, Moscow, Kronshtadskiy avenue, 32-A

Aleksandra Igorevna Andreeva

Institute for tourism and hospitality affiliate of Russia State University of Tourism and Services Studies, 125438, Moscow, Kronshtadskiy avenue, 32-A

\section{Maria Igorevna Seredina}

Institute for tourism and hospitality affiliate of Russia State University of Tourism and Services Studies, 125438, Moscow, Kronshtadskiy avenue, 32-A

Doi:10.5901/mjss.2015.v6n5s2p58

\section{Abstract}

The relevance of the art-exhibition activities as an innovative tool in enterprises of due to current trends in the hospitality industry, in hotels increasingly is activities of a cultural nature. The aim of this work is to determine the exposure opportunities of hotel enterprises as innovative technologies of the modern hotel business. The organizational structure of a hotel enterprise is conducive to the introduction of exhibition activities as an innovative tool. It is possible to perform a set of activities by fulltime employees of hotels, and in addition to hiring professionals, attracting private consultants, engaging in creative collaborations.

Keywords: Hospitality Company, exhibition activities, exhibition technology, innovative technology, socio-cultural communication.

\section{Introduction}

In Moscow every year, we open new cultural centers that are irrefutable proof of the interest and the needs of society to art and exhibition projects. According to the publication in "The Art Newspaper", in 15 years the average attendance of the most successful exhibitions increased by about five thousand people from three to eight.

Another indicator of the development of the Russian art market is the emergence of special financial and banking services in the field of storage, insurance and trafficking of works of art, as well as credit against their collateral. And since 1991, Russia has held regular auctions of Antiques. The licenses for the Antiques trade have 140 companies in 20 Russian cities. Antique Empire Sotheby's and Christie's in recent years have introduced the Directors on projects with Russia. No accident these well-known auction houses before arranging trades in New York or London, often first was brought to Moscow at an exhibition of paintings by artists of international renown worth millions of dollars (http://artinvestment.ru; http://www.christies.com).

Comparing Russian exhibition practice from overseas, I can say that here much later, after the 1990s, the 
exhibition was carried out outside of institutional structures (Dukhovnaya, L. L., et al.,2014).

The art market in Russia is only beginning to emerge, and experts are in no hurry to call it reliable. First, because Russian infrastructure remains underdeveloped: in contrast to international practice we still have place for development and formation of companies, specializing in the creation of the art indices, ratings and the organization of auctions.

Secondly, because so far the operation on the Russian market is the subject to many risks: too high percentage of fakes among Russian "antiquity" and the avant-garde. Thirdly, in comparison with European countries and the US, the turnover of art in our country is negligible - due to the fact that the market is still a shadow.

\section{Technique}

Experience shows that all the countries, considerably amplified in recent times, its position in the global art space, active use of the potential of exhibitions and congresses in hotel companies. According to the research center MA Step by Step concentration of showrooms in Moscow hotels is quite high.

These data are illustrated in the figure 1.

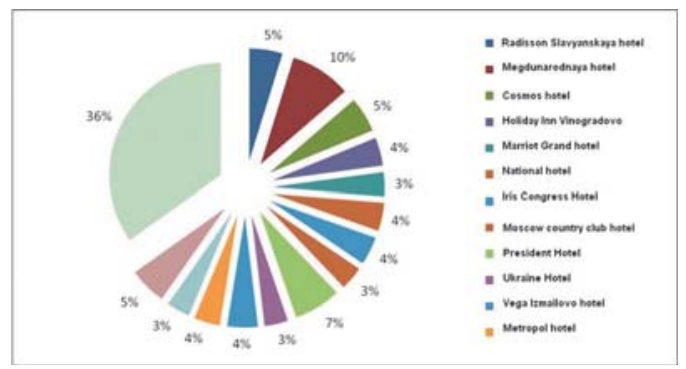

Figure 1. The concentration of the exhibition halls in hotels, \% (http://www.step-by-step.ru)

Figure 1 shows that $64 \%$ of the exhibition halls are accommodated in the hotels category "five stars".

Public groups and art project, in which various kinds of communication are:

- the authors of works of art (painters, sculptors, photographers, etc.);

- art-critics (critics);

- Media (journalists and publications specializing in the field of culture);

- private collectors;

- representatives of the artistic scene (writers, actors);

- visitors, viewers;

- $\quad$ staff (curator, the gallery administrator, Director);

- public authorities (Ministry of culture);

- the educational institution.

These data are illustrated in figure 2.

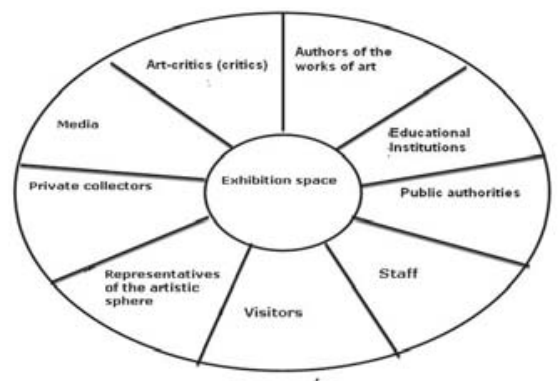

Figure 2. Public group art project, where are various kinds of communication 
From figure 2, all the community groups who participate in cultural activities. In the centre stands "exhibition space" - this is the main point, a place where cultural communication takes place, which is possible to organize in the hotel business (Lee, G., et al., 2005; Stabler, M. A. and P. T. Sinclair, 2010).

\subsection{The hotel "Radisson Royal hotel Moscow (former hotel "Ukraine").}

The hotel is located on Dorogomilovskaya at the bend of the Moskva river, in an open area, where are two major Metropolitan roads - New Arbat and Kutuzovsky prospect. 29-storey hotel with a high spire and corner towers is visible from different points of the city, and at night, with lights, is a uniquely beautiful sight. The main facade of the hotel is facing the Moscow River and the city center. Picturesque Green Square, where in 1974 was a monument to Taras Shevchenko, descends from the facade to the granite embankment of the river and the stairs that lead to the water. The construction of the hotel "Ukraine" began in 1953, under the project of architects A. V. Mordvinova and Kalisz, engineer P. Krasilnikov. A project of this magnitude required the use of all technological developments and the latest techniques that would provide not only strength and security of the building and coordinating the work of a giant hotel complex. The facade was decorated with moldings and other decorative elements, which were also, used Soviet symbols - the obelisks, the Attica of five-pointed stars, vases in the form of sheaves of wheat. The main hotel entrance was a marble, and the Central hall was decorated with round picturesque plafond "labor day and harvest on hospitable Ukraine". Splendor was different and the interiors of the hotel - mosaic parquet, bronze chandeliers, massive furniture. A subject of special pride of "Ukraine" was the collection of paintings, in which there are over a thousand paintings. Most of these works were created in the 1950s specifically for the interiors of the hotel "Ukraine" - on the order worked for several art workshops. Since the late 1950s, the hotel "Ukraine" and now "Radisson Royal Moscow", preserved interiors, which reflect the atmosphere of those years. In the three-year renovation was equipped with modern technical equipments, high-tech engineering systems and communications, multi-stage filtration system water and air, advanced fire safety system and multimedia equipment. The collection of works of fine art hotel "Ukraine" has over one thousand two hundred paintings. Here are the canvases by renowned and recognizable authors, the classics of socialist realism - Alexander Deineka, Aristarchus Lentulov, Dmitry Nalbandian, Nicholas Romadin, Michael Suzdaltsev, Kukryniksy, and many others, not so widely known among art lovers. Among the artists of the Soviet era explicit interest also Romas J., M. Birshtein, A. Nikich, S. Lukashkin, and E. M. Aslamazyan, P. Sokolov-Skal, N. Denisov,M.Ivanov.

The gem of the collection of works by Vasily Polenov with Museum value dated 1910-1912 sketches made during his stay in the Crimea, in particular in Sudak. Most works created after the war, until the late 1950s, and provided hotel Combine pictorial and decorative arts of the Art Fund of the RSFSR. During the restoration of the hotel from March 2007 to April 2010, her collection of cultural artifacts has been enriched with new acquisitions: a diorama of Moscow and the collection of sculptures from the Soviet era have 57 excellent works. The collection of sculptures is of artistic value and consists of unique finds, collected as a result of working with the talented sculptors from Moscow and St. Petersburg workshops. Some of the sculptures were recovered, others were cast anew. Vivid images of the era of socialist realism are emphasized ideological and folk, allegorical and portrait created from marble, bronze, plaster or porcelain - filled space of life. Pushkin, Lermontov, Yesenin, Chekhov, Tolstoy, Mayakovsky, Kutuzov, Gagarin never been to the hotel Ukraine, but now live here, embodied more than half a century ago, a brilliant cutter and sensitive fingers of craftsmensculptors P. A. Yakimovich, M. R. Gable, O. K. Komov, A. A. Murzin, I. A. Jankovoy., A. M. Ignatieff and the famous painter-sculptor, the author of the unique sculptures that adorn the Moscow metro, - G. I. Motovilov and in the halls of exhibitions of art collections not owned by the hotel. At the hotel on contractual relations shall hold the auctions Western auction houses.

\subsection{Hotel "National".}

This is a unique hotel, an active Museum, which welcomes guests in the historic interiors. In its early days more than a century of history the hotel has welcomed distinguished guests of the last Russian Tsar and members of reigning dynasties of Europe. After the revolution of 1917 "National" has become in a short period of time home to the Soviet government, which included the hotel lived, Lenin, Dzerzhinsky, Trotsky, and later the hotel was converted into the First House of Soviets - a dormitory for the nascent Soviet nomenclature. During the Second World War, "National" was a residence of 16 foreign embassies and diplomatic missions. Among items of interior decoration of the modern "National" personally belonged to the Royal family of Russia and perfectly preserved until now the pieces of furniture and works of art from Tsarskoye Selo and Anichkov Palace. Rare hotel can be compared with the "National" level historical artistic interior with unique pieces of furniture and interior decor, rare examples of painting and applied art, as well as the musical 
instruments Museum level.

\subsection{Hotel"Metropol"}

Hotel "Metropol" owes its birth to the famous patron of arts Savva Mamontov. In order to build a hotel of European level, he has assembled a team of young and talented artists and architects, among whom were Walcott, Vrubel, Kekushev and Chekhonin. The hotel building is an outstanding example of the modernist era, the Silver age of Russian culture (the period from the late XIX to the early XX century). The opening of the hotel "Metropol" was held in 1901, when the Muscovites came in crowds to see the "tower of Babel XX century" - this was the name of the hotel "Metropol" in those days. No hotel in Russia, in addition to it, we could not boast of hot water, refrigerators, elevators, and telephones. The rooms and restaurants were filled with sophisticated public. The interiors of the "Metropole" often were visited by famous manufacturers (Morozov, Ryabushinsky) and artists (Bruce, Komissarzhevskaya, Chaliapin and Rachmaninoff). In 1917 the Bolshevik government moved from Petrograd (former Saint Petersburg) to Moscow, hotel "Metropol" has become the headquarters of the all-Russian Central Executive Committee. New residence became known as the Second house of the Soviets. At the "Metropol" lived and worked Chicherin, Sverdlov and Bukharin. In 30-ies of the XX century "Metropol" regained its status of the highest class. If the Soviet government wished to win the favor of the foreign guests, among them there were George Bernard Shaw and Bertolt Brecht, such guests were placed in the "Metropol". During the Second World War among the guests was dominated by Western correspondents publications, and the hotel was organized by the press center. Modern hotel "Metropol" has rightly become a symbol of Moscow for many foreign tourists and businessmen. Some of Moscow's old buildings certainly have this kind of appeal. In them there are historical events in their neighborhoods intertwined human fate, they have become an integral part of the era. And "Metropol" is one of these buildings. In addition, to the features of as such, "Metropol" is on a mission "historic hotel" and a hotel-Museum. Even Savva Mamontov wanted to build on a place of cultural and leisure centre and to hold recitals. The internal decoration had a hand in such "pillars" of the world-artists as Viktor Vasnetsov, Vasily Polenov and Konstantin Korovin. At different times in the "Metropol" exhibited works of art by Jean-Charles de Castelbajac Pierre Henri Matisse, Wolf Von Lenkevich and other great artists. At the hotel on contractual relations will be hold the auctions Western and Russian auction house (http://www.museum.ru).

\subsection{Hotel "Swissotel Red Hills"}

The hotel towering over Kosmodamianskaya quay is a modern 34-storey building which blends with the beautiful landscape. The location of "Swissotel Red Hills" is near the confluent of the Moscow River and the catch water drain. This gives guests the opportunity to be literally in the center of cultural and business life of the capital. There is the largest concert hall of Moscow - Moscow International House of Music, Paveletsky station with a station of Aeroexpress to the airport "Domodedovo", Moscow's largest business centers and a variety of restaurants and bars in close proximity to the hotel. "Swissotel Red Hills" is an ideal choice for both business people and tourists who want to learn the capital as better as possible. Three-four meter canvases of Russian artists are exhibited in the hotel halls. Any visitor can buy them if he wants.

\subsection{Hotel "Savoy"}

In 1909, it was bought by the Salamander Fire Insurance Company. The renovation of the building began and it was supervised by the architect Viktor Yushchenko -Velichkin. The luxurious Rococo interior of the cafe was carried out according to the project of the artist A.A. Tomashki. Its point of interest was the magnificent painted ceiling decorated with irregularly shaped mirrors. The first guests stayed in the "Savoy" on March $30^{\text {th }}, 1913$. The opening of the hotel, which coincided with the opening of the renovated restaurant, was celebrated with a grand banquet. After the October 1917 "Savoy" continued to exist, first submitting to the Office Moscow Council hotel administration, then incorporating with "Metropol" and "National" into the All-Union Company "Hotel", later known as the "Intourist" which was created to serve foreigners. In 1989, after the restoration works aimed at restoring the historic interiors, the hotel was opened taken its original name. Among the guests of "Savoy" for nearly one hundred years of its existence there were Yesenin and Isadora Duncan, Henri Barbusse, Luciano Pavarotti, Jose Carreras, Lucia Aliberti, Patricia Kaas, Richard Gere, Julia Ormond, Dave Brubeck. Paintings by contemporary Russian and Italian artists are exhibited In the halls of the reception-room and the restaurant. Work performed in the classical style with oil, guests can buy any of them. Especially it's not reported but there are small signs with basic information (artist, year, technique) under each picture. 


\subsection{Hotel "Ararat Park Hyatt Moscow"}

The ultra-modern five-star design hotel in Moscow of international level, is specially created for the exacting traveler who estimate privacy, personalized service and excellent quality. The hotel is located in the historical center of Moscow near Red Square and just a few steps from the Kremlin, the Bolshoi Theatre, the building of the State Duma, the business center of Moscow and the legendary shopping malls TsUM and GUM. The hotel has 206 magnificent rooms, including 32 suites with individual designs by Tony Chi, which combines elegance and home comfort . "Ararat Park Hyatt Moscow" often holds exhibitions, shows, festivals and sales. The company does not have its own collection, all art exhibitions are held in cooperation with various cultural organizations. Also, the hotel provides space for rent for group exhibitions and sales of works of art.

\subsection{The hotel "Marco Polo Presnja "}

The hotel "Marco Polo Presnja" was built in 1904. Artists, politicians and cultural figures stayed here at different times. In 1999 the building was reconstructed in such a way as to preserve the facade of the hotel. Hotel lobby is constantly decorated with paintings by various artists, the exhibition is changed frequently. In the premises of the hotel enterprise there are exhibitions of paintings by famous artists and young artists - a kind of "flagship product" of the hotel. The hotel does not collect its own collection. Art exhibitions are held together with other members of the creative industries. All works are often sold, as well as charity exhibitions and sales are organized there.

\subsection{Hotel "Marriott Royal Aurora"}

It's located in the heart of Moscow, near the Kremlin and Red Square. A few steps from the hotel there is the worldfamous Bolshoi Theatre. Russian historical traditions are combined with modern comfort and refined luxury. The tenders of Russian auction houses and exhibition- sales are always held in the hotel. But it does not have its own collection of art.

\section{Results}

In the result of the analysis of eight five-star hotels, we can conclude that the art and exhibition work is held quite actively and in various forms. The hotel "Ukraine", "National" and "Metropol" actualize the cultural and historical memory of the country, working on conservation and restoration of objects of Museum value. More than that, the hotel "Ukraine" constantly increases its own store-rooms of art collections and thus improves the overall investment value of the enterprise.

Hotel enterprise "Savoy", "Swissotel Red Hills", "Ararat Park Hyatt Moscow", "Marco Polo Presnja" and "MARRIOTT Royal Aurora" lease their areas, enter the creative collaborations and hold regular sales art exhibitions and shows of art works, this all can enrich the budget of the enterprise (http://marriottmoscowroyalaurora.ru; http://radisson.ru/ royalhotel-moscow).

All eight examined companies successfully use cognitive-communicative method in the work with visitors, what increases the sympathy of the public to the enterprise.

Only several companies have special exhibition equipment. If art can serve as a continuation of the harmonious design of hospitality apartments, the company organizes special equipment for them. Such as:

- suspension system;

- special lighting;

- the captions.

Taking into account the development and formation of exhibition activities as a special industry in Russia, economic efficiency of partnerships within the limits of Hotel Corporation is undoubted. Art and exhibition structures receives strong support; creative projects increase capitalization; cultural and artistic ideas become more expensive; the city's budget is significantly replenished. The hotel acts as a generator of social and cultural and artistic innovation (Tebekin A. V., 2013).

Social-cultural communication in the hospitality industry becomes an important element in creating strong links between the visitors and hotel company. The result is the atmosphere of understanding and awareness in this chain, consisting of a hotel enterprise the object of exposition and the spectator. When there is the minimum investment of resources in the implementation of innovative technologies, all activities find the creatively oriented concept, and the hotel 
becomes a powerful and inexhaustible source of independent income. With state support, such corporations can become a powerful business culture, form and develop their own market of services in the sphere of art (Yureneva T. Y., 2010, Lebedev A. V., 2014).

\section{Conclusion}

\subsection{The administrative apparatus}

Exhibition activities of the hotel enterprise shall be managed by a specially created cultural administrative department. Depending on the tasks it can include:

- Manager;

- Curator;

- Arts critic;

- Hall administrator.

Priority task is setting up objectives and the allocation of the curatorial direction of the course (definition of types, objects of art that will be exhibited). The exhibition can be divided into commercial and non-commercial ones(Misiano, $\mathrm{V}$. A., 2014).

Commercial exhibitions are exhibitions of works of art in order to derive direct financial benefit.

Non-commercial exhibitions are exhibitions of works of art which aim is the actualization, the presentation of exhibition material to the public.

The organization of the Art and Exhibition Department may be made by General Manager of the hotel enterprise and its management. Art and Exhibition Department may consist of one employee - Manager, his or her position shall be provided in the staffing of the hotel enterprise; other professionals may be hired for the duration of the exhibition project, depending on objectives. Technical preparations for the exhibition must be divided among staff carpenters, technicians and other laborers of the hotel enterprise. Combined careers depend on the size of the staff, they include the specialties associated with the exploitation of the building, managers, custodians, carpenters, curators, illustrators and artists, forwarding agents and employees of the security service (Hudson, K., 2012).

Works of art can be presented in the spaces of the hotel as permanent exhibitions or short-term exhibitions. The hotel collection can be enriched with following ways:

- $\quad$ purchase of works of art laid with the funds of the enterprise;

- the completion of the collection at the expense of hotel rooms, the introduction of the service "pay for the room with art";

- the expansion of collection of works obtained through exhibitions (A. J. Jacobson, 2010).

Many hotel companies have their own collections and do not plan to do the gathering. Exhibition opportunities don't decrease. Hospitality company may use the following works for exposure in the area of the hotel on contractual relationships:

- series of works of artists, working directly with exhibition halls;

- the collection of objects of heirs, holders, collectors;

- collection of works of the third-party public and private organizations (auction houses, museums, galleries and other cultural institutions).

In the case of an undefined exhibition activity of the enterprise the manager can charge curators, art historians or art dealers with the development of exhibition projects on contractual relationships. In this case Manager of the exhibition Department of the hotel will coordinate the whole process of the exhibition.

The exposition of the hotel is only the part of the work. The broader mission of the Exhibition Department is the collection, preservation, studying, and displaying of objects of artistic, historical, scientific and cultural importance. Research and preservation of collections, invisible for the visitor, form the largest part of the work. A collection usually represents only a small portion of the total funds. The rest is kept in storage or is temporarily given to other exhibitions or research projects (http://expobusiness.ru).

The management of the art collection and the collection of artifacts includes acquirement of works, inventory management, proper storage techniques, preservation of exhibits and pest control, moving samples, pest control, preparation of these samples for exposure and further storage in the duties of the supervisors or managers. 


\subsection{Material and technical regulation}

While planning the exhibition space it's necessary to explore in detail the actual movement of visitors and hotel guests in the premises. It is better that the exhibition space is located in a conspicuous place near the entrance or in the course of movement of the main streams of visitors.

The mounting system must have a large width in the front (if the inside entry of visitors isn't provided). The main thing is not the quantity but the quality of the exhibition spaces, the ability of original design of stands without disturbing the exterior of hotel space, of picking up of the exhibits and of making exposition interesting and memorable for the visitor (http:///vww.lomonosov-fiind.ru).

After compiling the list of exhibits you should conduct measurement (dimensions, weight and number). Choosing exhibits for exhibition in the hotel, you should be guided by the following rules:

- focus on target groups to which exposition is addressed;

- exhibits must not disrupt the overall look of the exterior of the premises;

- exhibits must not cause harm to any person presenting at the premises;

- exhibits must show the primary theme of the exhibition;

- exhibits must not obstruct all of the walls;

- exhibits should not be located on the aisle (Obrist, H. U. 2014; Chernenko, V. et al., 2013).

Having defined the theme of the exhibition, with the exhibition material, you need to develop a plan of exposure. The plan should also include:

- the area for accommodation of exhibits (tables, display cases, shelves);

- a sufficient number of sockets for connection of exhibits or lighting devices;

- the area for accommodation of the explication and promotional materials of the exhibition.

Fabrication of all necessary equipment, fixtures, tablets for annotation, etc. is made on the basis of layout sheets; the installation of the exhibition is carried out. Approximate placement of exhibits in accordance with layout sheets is carried out to clarify and correct any error before the final assembling, the visual compatibility of the exhibits and the overall impression of the exhibition are checked during this process.

Exhibition activity as a component of the hospitality industry has recently became the object of study in Russia, so it is still not well understood for effective use of the existing recommendations. It should be noted the lack of scientific papers on the study of this problem, especially on security issues of exhibition activity in the hotel area.

\section{References}

Lee, G., Morrison A.A., Lheto X.Y., Webb J. and Reid J. (2005) VFR: Is it really marginal? A financial consideration of French overseas travelers. Journal of Vacation Marketing 11: 24-37.

Stabler, M.A. and Sinclair P.T. (2010) The Economics of Tourism 2nd Edition,London: Routledge, pp: 180.

Dukhovnaya L.L., Kholodtsova I.I., Polyakov V.V. (2014) Comparative analysis of the hotel marketing in the Russian Federation and abroad. Life Science Journal, pp: 251.

Misiano, V. A. (2014) Five lectures on curating. - AdMarginemPress.

Obrist H.U. (2013) Brief history of curating. - AdMarginemPress.

Tebekin A.V. (2013) Innovative management. - M.: Yurait.

Hudson K. (2012) Corporate culture and change management. - Publisher: Alpina Business Books.

Chernenko V., Kachalova, O., Loktev O. (2013) Current trends in the development of hotel service. Technical-technological problems of the service, \#1 (23).

Yureneva T. U. (2010) Museum communication: foundations and models of cultural analysis/ Cultural studies: the fundamental basis of applied research . In I. M. Bykhovskaya (Ed.) - M: Meaning.

Jacobson A. J. (2012) Innovative management. - M.: Omega-L.

Lebedev V. A. (2014, October 22) Museum representation on the Internet. Russian and foreign experience. http://www.ict.edu.ru/ft/ 003570/mus_nt.pdf

MA website Step by Step - a group of companies involved in Analytics and consulting. (2014, October 22) http://www.step-by-step.ru

Museums of Russia - the electronic portal. (2014, October 24) http://www.museum.ru

Guide to exhibitions activities. (2014, October 25) http://expobusiness.ru

Khangeldieva I. G. Gallery business. (2014, October 22)http:///lwww.lomonosov-fiind.ru

Official website of the Hotel "Marriott Royal Aurora". (2014, October 22) http://marriottmoscowroyalaurora.ru

Art News Paper. com (2014, October 24) monthly paper publication publishing news in the art world.

Official website of the Hotel "Radisson Royal Moscow". (2014, October 22) http://radisson.ru/royalhotel-moscow

ARTinvestment.Ru - Internet project dedicated to the art market. (2014, October 23) http://artinvestment.ru. -

Christie's - the auction house's official website. (2014, October 25) http://www.christies.com 